NBER WORKING PAPER SERIES

\title{
AGE DISCRIMINATION LEGISLATION IN THE UNITED STATES
}

\author{
David Neumark
}

Working Paper 8152

http://www.nber.org/papers/w8152

\author{
NATIONAL BUREAU OF ECONOMIC RESEARCH \\ 1050 Massachusetts Avenue \\ Cambridge, MA 02138 \\ March 2001
}

Professor of Economics at Michigan State University, Visiting Fellow at the Public Policy Institute of California, and Research Associate of the NBER. Scott Adams, Robert Hutchens, and Richard Posner provided helpful comments. The views expressed are those of the author only, and do not reflect those of the Public Policy Institute of California. This paper was prepared for the Rowntree Foundation workshop on age discrimination, London, March 2001. Much of the author's research on age discrimination was supported by the National Institute on Aging, grant K01-AG00589. The views expressed herein are those of the author and not necessarily those of the National Bureau of Economic Research.

(C) 2001 by David Neumark. All rights reserved. Short sections of text, not to exceed two paragraphs, may be quoted without explicit permission provided that full credit, including (C) notice, is given to the source. 
Age Discrimination Legislation in the United States

David Neumark

NBER Working Paper No. 8152

March 2001

JEL No. J1, J7, G31

\begin{abstract}
Legislation prohibiting age discrimination in the United States dates back to the decade of the 1960s, when along with the Equal Pay Act and the Civil Rights Act barring discrimination against women and minorities, the U.S. Congress passed the 1967 Age Discrimination in Employment Act. Many critical issues regarding the rationale for or effectiveness of age discrimination legislation have been addressed, and continue to be studied, by researchers in both economics and law, while many questions remain. These questions are likely to become increasingly important as rapidly aging workforces in the United States and other industrialized countries threaten to vastly increase the social costs of any barriers to older workers' employment.

This paper provides a summary, critical review, and synthesis of what we know about age discrimination legislation. It first traces out the legislative history and the evolving case law, and discusses implementation of the law. It then moves on to review the existing research on age discrimination legislation-research that addresses the rationale for the legislation, evidence on its effectiveness, and criticisms of age discrimination legislation.
\end{abstract}

David Neumark

Public Policy Institute of California

500 Washington St., Suite 800

San Francisco, CA 94111, Michigan State University, and NBER 


\section{$\underline{\text { I. Introduction }}$}

Legislation prohibiting age discrimination in the United States dates back to the decade of the 1960s, when along with the Equal Pay Act and the Civil Rights Act barring discrimination against women and minorities, the U.S. Congress passed the 1967 Age Discrimination in Employment Act. Sex and race discrimination per se, along with the impact of the Equal Pay Act and Civil Rights Act, have been the primary focus of researchers studying discrimination, and coupled with affirmative action, by far the more vociferously debated. But this does not imply that issues regarding the rationale for or effectiveness of age discrimination legislation are settled. Indeed, some critical issues have been addressed, and continue to be studied, by researchers in both economics and law, although many questions remain. The debate may have been far more muted than that over sex and race discrimination not so much because there is a consensus, but rather because all individuals can expect to some day enter the class of individuals protected by age discrimination laws, so that issues of fairness are perhaps less prominent. Nonetheless, the issue is fundamental, especially as rapidly aging workforces in the United States and other industrialized countries threaten to vastly increase the social costs of any barriers to older workers' employment.

The goal of this paper is to provide a summary, critical review, and synthesis of what we know about age discrimination legislation. In so doing, the paper first traces out the legislative history and the evolving case law, and discusses implementation of the law. It then moves on to review the existing research on age discrimination legislation-research that addresses the rationale for the legislation, evidence on its effectiveness, and criticisms of age discrimination legislation.

\section{Age Discrimination Legislation in the United States}

\section{A. The Evolution of Age Discrimination Legislation}

Most discussions of age discrimination legislation in the United States refer to the 1967 Age Discrimination in Employment Act (ADEA), and subsequent amendments. But age discrimination legislation in the United States has a longer history. At the federal level, the United States Civil Service 
Commission abolished maximum ages of entry into employment in 1956, eliminating age discrimination in hiring in federal employment (Miller, 1966). Paralleling the executive orders that established affirmative action, Executive Order 11141, issued in 1964, established a policy against age discrimination among federal contractors, although administrative procedures for handling complaints were apparently not established (Miller, 1966). Finally, the 1965 Older Americans Act was designed to encourage research and programs to aid the aged, but also stated among its general objectives "the opportunity for employment with no discriminatory personnel practices because of age." Again, though, no administrative procedures were established.

While the federal actions prior to the ADEA were therefore perhaps best characterized as ineffectual and having little teeth, state statutes paralleling the later federal legislation were passed beginning in the 1930s, and as of 1960 eight states had age discrimination statutes on the books, with enforcement mechanisms. ${ }^{1}$ These state statutes were part of states' Fair Employment Practices Acts, which established state-level commissions to counter discrimination. These commissions operated by first seeking conciliation in response to claims of age discrimination. But in the absence of a satisfactory outcome they had the power to hold hearings, issue findings of probable cause, and seek court-enforced orders for employers to cease and desist from discriminatory practices (Lockard, 1968; Miller, 1966). ${ }^{2}$ Evidence on the effects of the state statutes is discussed below, but it is noteworthy that when federal legislation was later established, the role of anti-discrimination commissions in states with their own age discrimination statutes was explicitly recognized, with enforcement generally first deferred to the state agency responsible for enforcing the anti-discrimination statute (U.S. Code, Section 633). This pertained to many states that enacted age discrimination legislation in the 1960 s as well. ${ }^{3}$

${ }^{1}$ See Neumark and Stock (1999) for a compendium of state age discrimination laws.

${ }^{2}$ For more discussion of state anti-discrimination statutes in the context of race discrimination, see Neumark and Stock (2000).

${ }^{3}$ See also U.S. Department of Labor (1965) and Friedman (1984) for discussions of the effectiveness of state laws. 
Federal legislation, which is summarized in Table 1, began in earnest with the 1967 ADEA. The original ADEA prohibited discrimination based on age, covering those aged 40-65, and including discrimination based on age within this protected age range (Piette, 1995). ${ }^{4}$ As originally stated, the purpose of the Act was to "promote employment of older persons based on their ability rather than age; to prohibit arbitrary age discrimination in employment; to help employers and workers find ways of meeting problems arising from the impact of age on employment" (U.S. Code, Section 621).

Crawshaw-Lewis (1996) argues that the "arbitrary age discrimination" that the original legislation was intended to eliminate was discrimination against older individuals based largely on negative stereotypes. She cites the record of the debate from the Congressional Record:

The bill recognizes two distinct types of unfair discrimination based on age: First, the discrimination which is the result of misunderstanding of the relationship of age to usefulness; and second, the discrimination which is a result of a deliberate disregard of a worker's value solely because of age. (p. 770)

As further elaboration, Crawshaw-Lewis cites the ruling from Hazen Paper Co. v. Biggins (1993), indicating that Congress passed the ADEA out of concern that "older workers were being deprived of employment on the basis of inaccurate and stigmatizing stereotypes."

The ADEA was followed by the 1975 Age Discrimination Act, which prohibited age discrimination in all programs or activities receiving federal assistance, including state or local government units that receive federal funds. Important amendments or changes to the ADEA occurred in 1978, 1979, and 1986. The 1978 amendments extended the age range for the protected group to 40-70, hence raising the mandatory retirement age to 70 in the process. They also eliminated mandatory retirement for most federal employees (Stone, 1980). But the 1978 amendments also granted some exemptions, delaying the imposition of the higher mandatory retirement age until 1982 for tenured employees of educational institutions, and continuing to allow mandatory retirement at ages 65-69 for

${ }^{4}$ The ADEA originally applied to federal and state employees. However, in a recent case (Kimel v. Florida Board of Regents, 2000) the courts ruled that state employees were not authorized to sue states under the ADEA, based on the argument that the U.S. Constitution does not give the U.S. Congress the power to subject states to suits at the hands of private individuals. 
individuals in "bona fide executive or high policy-making" positions with access to a sufficiently high pension benefit (Stone, 1980), and for employers with fewer than 20 employees. ${ }^{5}$ The ADEA currently covers all private employers with 20 or more employees, state and local governments (including school districts), the federal government, employment agencies, and labor organizations.

An important change occurred in 1979, when the U.S. Equal Employment Opportunity Commission (EEOC) took over administrative responsibility for the ADEA from the Department of Labor and, regarding federal employment, from the U.S. Civil Service Commission (Stone, 1980). This change was viewed as increasing the power of the ADEA, as it was accompanied by increased resources and a greater prevalence of "pattern and practice" lawsuits (by the EEOC).

The last direct amendments to the ADEA were 1986 amendments eliminating the upper age range for defining the protected class, and hence resulting in the prohibition of mandatory retirement. As this took away the most direct lever for employers to induce workers to retire from the firm, the focus switched to some extent to financial inducements. These were addressed in the 1990 Older Workers Benefits Protection Act (OWBPA), which provided some restrictions on financial inducements to retire. One of the important restrictions was the requirement that retirement incentive schemes be offered to anyone over a minimum age, rather than to workers in a specific age range. The second was that offsets of pensions benefits against severance payments were limited. These are viewed as having restricted to some extent the ability of employers to induce retirement through financial incentives (Issacharoff and Worth Harris, 1997). On the other hand, the OWBPA is viewed as having codified the types of retirement incentives that can be used (Albert and Schelberg, 1989). ${ }^{6}$

\footnotetext{
${ }^{5}$ These amendments also established the right to a jury trial when there were factual issues regarding monetary liabilities.

${ }^{6} \mathrm{An}$ important piece of legislation regulating pension (and other) benefits, and potentially impacting opportunistic behavior of employers toward older workers, was the Employees Retirement Income Security Act (ERISA) of 1975. Posner (1995, Ch. 12) provides an excellent overview of pension regulations.
} 


\section{B. Prohibited and Allowed Practices Under the ADEA}

The current ADEA has many parallels to Title VII of the Civil Rights Act prohibiting sex and race discrimination, and hence defines as illegal many of the same activities prohibited under Title VII. ${ }^{7}$ In addition, reflecting this parallel, the legal interpretations of the ADEA and Title VII are to some extent intertwined, as discussed below. Prohibited actions include using an individual's age as a basis for refusal to hire an applicant, discharge of an employee, or the setting of other conditions of employment (compensation, or terms, conditions, or privileges of employment). The Act also regulates the behavior of employment agencies and labor unions. Among other things, these two types of agents, as well as employers, are prohibited from using any advertisement relating to employment indicating preferences, limitations, etc., based on age (U.S. Code, Section 623).

At the same time, the ADEA recognizes that there are some differences regarding the treatment of age in the labor market. In this sense, it differs from Title VII, which while granting some very limited exceptions in which sex or race can play a role in labor markets (e.g., in occupations such as locker room attendants and actors), largely treats sex and race as factors to be ignored. For example, the ADEA recognizes the role of seniority systems, and as such protects the use of a bona fide seniority system, as long as it is not used to evade the purposes of the Act. It also recognizes that some work limitations may arise with age,${ }^{8}$ and hence permits the use of age as a bona fide occupational qualification (BFQ) that is "reasonably necessary to the normal operation of a business." Finally, it recognizes that costs related to benefits may be higher for older workers, and makes some allowances for this; in particular, an employer can offer younger and older workers benefits that cost the same, even if the actual benefit to older

${ }^{7}$ Indeed, the ADEA had its origins in Title VII. Members of the House and Senate initially tried to introduce a prohibition of age discrimination into Title VII (Crawshaw-Lewis, 1996), but eventually settled on instructing the Secretary of Labor to study age discrimination in employment, with the goal of recommending legislation "to prevent arbitrary discrimination in employment because of age." This led to the enactment of the ADEA three years later (Stone, 1980).

${ }^{8}$ As discussed below, there is conflicting evidence on this question in the industrial gerontology literature. See the studies cited in Hellerstein and Neumark (1995, footnote 2), Miller (1966, pp. 395-9), and Posner (1995, Ch. 4 and Ch. 7). 
workers is less. At the same time, there was a clear sense that employers sometimes relied on incorrect stereotypes regarding age. ${ }^{9}$ Finally, the ADEA recognized that employee pension plans (and potentially other benefits) are inextricably bound up with both age and seniority, and established careful guidelines to clarify what was and was not permitted.

\section{Implementation of Age Discrimination Legislation}

\section{A. Enforcement}

Enforcement of the ADEA currently resides with the EEOC. Claims of age discrimination may emanate from individuals or from the EEOC. An individual wishing to pursue civil action on an age discrimination claim must first file a charge with EEOC or, in states with parallel age discrimination statutes, first file a charge at the state level. ${ }^{10}$ The EEOC's (or state agency's) role upon receiving a charge is to "eliminate any alleged unlawful practice by informal methods of conciliation, conference, and persuasion" (U.S. Code, Section 626).

After filing a charge, there are a number of possible outcomes. Depending on the facts of the charge, the EEOC can investigate with different levels of priority. The charge may be dismissed if the EEOC does not think there was a violation of law. If a charge is dismissed, the complainant may still pursue a civil action in court. ${ }^{11}$ If the charge is not dismissed, the EEOC can seek a settlement with the

\footnotetext{
${ }^{9}$ The Department of Labor report on age discrimination argued that age discrimination was fundamentally different from sex and race discrimination because it was based not on animus or antagonism toward older persons, but instead on assumptions "about the effect of age on their ability to do a job when there is in fact no basis for those assumptions" (U.S. Department of Labor, 1965, p. 20). The notion was not that the assumptions were never correct. As Miller (1966) puts it, "[T]he BFQ issue in age cases and in cases involving other forms of discrimination is that the age statutes contemplate the establishment of valid generalizations about the effect of age upon the physical ability to perform a particular kind of job; such a generalization, if based upon race or religion, would never be validated" (p. 393). However, the Department of Labor report argues that the use of incorrect assumptions (or stereotypes) constitutes the "arbitrary discrimination" that Congress expressed interest in prohibiting when, in Title VII, it instructed the Secretary of Labor to study age discrimination.

${ }^{10}$ For details on time limits, and additional discussion, see the EEOC's web site, www.eeoc.gov.

${ }^{11}$ Under the ADEA, a plaintiff has a right to a jury trial and liquidated damages. (Liquidated damages are those required to compensate for a loss, in contrast to punitive damages, which are in excess of actual damages and are intended to punish the offender.)
} 
agreement of both sides, or the charge may be mediated if both sides are interested. If conciliation or mediation are unsuccessful, the EEOC can decide to file suit. Or, if it nonetheless chooses not to file suit, the complainant may still due so.

According to the EEOC, possible remedies include: back pay; hiring, promotion or reinstatement; front pay; ${ }^{12}$ or other actions that will "make the individual whole." It is possible that payment of attorneys' fees, expert witness fees, and court costs may be sought. Finally, compensatory or punitive damages may be sought where a finding supports a charge of intentional discrimination, or if the employer acted with "malice or reckless indifference," although punitive damages cannot be sought from state and local governments.

\section{B. EEOC Activity}

Recent figures describing EEOC activities are presented in Tables 2 and 3. ${ }^{13}$ As explained above, EEOC activity is usually initiated by a complaint brought by an individual, although the EEOC can also bring lawsuits on its own accord. The figures in Table 2 provide some information on selected types of issues reflected in complaints filed with the EEOC, for fiscal year 2000. Figures are reported for the ADEA, Title VII, and all statutes, to provide some indication of the types of issues that are more or less likely to arise in charges filed under the ADEA. Because a single discrimination charge may cover multiple issues (and indeed multiple statutes), a breakdown by selected issues is reported, as well as the total number of charges.

The table reveals, first, that ADEA and Title VII charges account for a preponderance of those received at the EEOC (94.7 percent in 2000). Those types of issues that we might expect to figure more prominently in ADEA cases-such as benefits relating to pensions and retirement, layoffs, and

\footnotetext{
12“Front pay" compensates a victim in situations where in principle reinstatement or nondiscriminatory placement would be an available remedy, but either is not ordered or cannot be accomplished for reasons peculiar to the individual claim (for example, because of hostility between the parties). It is distinguished from "back pay," in which a victim is reinstated, and awarded pay that would have been received absent the prior discrimination.

${ }^{13}$ These figures come from the EEOC's web site, www.eeoc.gov, and directly from the EEOC.
} 
discharges-do so, although by only a small factor in the case of discharges. On the other hand, not surprisingly, issues more directly related to race or sex (such as sexual harassment) are rarely alleged in ADEA cases, and wage issues are somewhat less prevalent than in Title VII cases.

Table 3 reports on EEOC activity. ${ }^{14}$ Panel A covers the resolution of charges filed with the EEOC. ${ }^{15}$ Again, these are broken down by ADEA resolutions, Title VII resolutions, and the totals, although the distributions differ relatively little. Of the ADEA charges resolved in 1999, 5.3 percent were settled, which means that the charge was disposed of with benefits to the party that brought the charge, with the settlement recorded. In contrast, 3.7 percent were classified as withdrawals with benefits, meaning that the charge was withdrawn after the charging party received benefits. Nearly a quarter of cases (23.3 percent) were closed administratively, covering reasons like failure to communicate on the part of a charging party, closure of related litigation that makes the charge futile, a determination of no jurisdiction, etc. Of the remaining charges, the vast majority are found to be without reasonable cause, implying that the EEOC found no reasonable cause "to believe that discrimination occurred based upon evidence obtained in investigation.”

Next, Panel B of the table breaks down those charges in which there was a determination of reasonable cause, showing that in only about 14 percent of ADEA cases is there successful conciliation (compared with 25.5 percent for Title VII cases). Panel C of the table reports on EEOC litigation and monetary benefits, covering suits filed by the EEOC, or plaintiffs' suits joined by the EEOC. Clearly, only a small fraction of unsuccessful conciliations result in litigation by the EEOC, although the monetary benefits collected are quite high per lawsuit. ${ }^{16}$ The final row instead reports benefits excluding

\footnotetext{
${ }^{14}$ The charges included in these figures include those filed with the EEOC as well as those transferred to the EEOC from state Fair Employment Practice Agencies.

${ }^{15}$ This refers to resolutions occurring in the year, not necessarily resolution of charges filed in that year. Preliminary 2000 figures are not yet available, so these refer to 1999. But the numbers generally change very little from year to year.

${ }^{16}$ While the last row of Table 3 suggests roughly equal dollar amounts for ADEA and Title VII cases, this varies substantially from year to year, as the total amount is highly influenced by a few large cases.
} 
litigation. As the figures show, these can be as high or higher in total, but cover a far higher number of charges.

\section{C. Case Law}

Aside from the regulations issued by the EEOC, the effects of age discrimination legislation in practice are strongly influenced by the evolving case law, which over time helps to establish, among other things, the types of charges that will be found in violation of the ADEA, the types of cases (i.e., nature of evidence) that may be brought, and the burden of proof. It is worth pointing out that some of the critical case law arose in race discrimination cases brought under Title VII of the Civil Rights Act, rather than the ADEA. ${ }^{17}$ The most important case law is summarized in Table 4.

In ADEA cases, the plaintiff's ultimate burden is to prove that the action of the employer (typically) was taken on the basis of age, which does not require that age was the sole factor, but was the determining factor. As in other areas of discrimination, this can be proven in one of two ways. The first is to prove "disparate treatment," established in International Board of Teamsters v. United States (1977) and other cases, which requires proof that an employer intentionally treated someone less favorably because of their age (Starkman, 1992). Such cases are distinguished by requiring proof of discriminatory intent. As an example, several cases in the 1970's alleging failure to hire based on age focused on helpwanted advertising that stated or implied that older applicants would be treated less favorably (Piette, 1995). Other examples of proof of discriminatory intent may involve evidence that defendants referred to a worker or applicant as "too old," or made other disparaging comments about age. In these cases, plaintiffs first try to establish direct evidence of intent to discriminate, such as discriminatory statements. In the absence of such evidence, the precedents established in McDonnell Douglas v. Green (1973), and Texas Department of Community Affairs v. Burdine (1981) are used to determine whether intentional discrimination has occurred. First, the plaintiff tries to establish a prima facie case for discriminatory intent (which may rely in part on statistical evidence (Piette, 1995)), ruling out the most likely non-

\footnotetext{
${ }^{17}$ Issacharoff and Worth Harris (1997) critique the application of the race and sex discrimination "model" to age discrimination cases.
} 
discriminatory explanations of the action. The burden of proof then shifts to the employer to offer a legitimate non-discriminatory explanation. Finally, the plaintiff can then rebut the employer's explanation, most commonly by trying to prove that the non-discriminatory explanation is false (Crawshaw-Lewis, 1996). ${ }^{18}$

The second route is to prove "disparate impact," established in Griggs vs. Duke Power Co. (1971). Such cases do not rest on proving discriminatory intent, but require two things: first, that an employer's policy that may appear neutral in fact impacts older individuals more adversely; and second, that the practice cannot be justified by "business necessity" (Starkman, 1992). An instructive example is provided by fitness requirements for hiring into a job. These may appear neutral (because they are based on something other than age), but in many cases are apt to disproportionately disadvantage older workers or job applicants. Courts have generally found them allowable only if they can be demonstrated to be absolutely necessary for the specific tasks to be performed (Piette, 1995). Disparate impact cases are more likely to rely solely on statistical evidence (Piette, 1995), in part because such cases have to establish the differences in how the practices in question impacted different groups, and in part because it is not necessary to prove discriminatory intent. Relative to race and sex discrimination cases, disparate impact claims are less common under the ADEA (Lindemann Schlei and Grossman, 1983), because establishing "legal significance" is difficult when the standard is a comparison to what would occur as part of the normal progression of older workers out of the labor force and their replacement with younger workers (Kephart v. Institute of Gas Technology, 1981). According to Crawshaw-Lewis (1996), recent court rulings have undermined the use of disparate impact cases under the ADEA.

To here, the discussion of case law applies equally well to the ADEA and Title VII of the Civil Rights Act. But case law surrounding the ADEA has had to wrestle with the unique problem of allowing employers to pay some attention to age; as noted above, the ADEA only prohibits "arbitrary age

\footnotetext{
${ }^{18}$ Crawshaw-Lewis (1996) criticizes the use of the McDonnell Douglas/Burdine test to determine whether age discrimination occurred, arguing that it pays insufficient attention to animus and stereotyping based on age, and has difficulty sorting out whether age actually motivated a decision (p. 771).
} 
discrimination." Specifically, the ADEA allows employers to take actions "where the differentiation is based on reasonable factors other than age ..." (U.S. Code, Section 623); this phrase introduced the "reasonable factors other than age" (RFOA) defense. As examples of this, in Mastie v. Great Lakes Steel Corp. (1976) the court ruled that an employer could look at salary and fringe benefit costs in determining which workers to dismiss in a "reduction in force," as long as the decision is "predicated upon an individual as opposed to a general assessment." Focusing on the salary issue, in Metz v. Transit Mix, Inc. (1987), the court ruled explicitly on the question of the "excessive salary" of an older worker, deciding that allowing the company to replace the employee based on the higher cost of employing him would violate the intent of the ADEA. The court raised two issues. First, the plaintiff's salary was based directly on years of service (although not age per se), and second, the defendant did not offer to reduce the salary paid to the plaintiff. Metz opened the courts to consideration of age discrimination claims in dismissal cases based on high salaries, requiring plaintiffs to show that age and salary were strongly linked, and that salary motivated the decision (Crawshaw-Lewis, 1996). In other cases, though (e.g., Holt v. Gamewell, 1986), the courts disallowed age discrimination claims based on salary considerations. Thus, through the Metz decision, Crawshaw-Lewis concludes that "plaintiffs charging age discrimination based on salary have encountered a decidedly mixed reception" (1996, p. 779).

A second fundamental issue in ADEA cases concerns pension status. In Hazen Paper Co. v. Biggins, the U.S. Supreme Court on the one hand noted that the ADEA was concerned with employment decisions based on age stereotyping, but on the other hand allowed decisions to be based on factors like seniority that may be strongly correlated with (but analytically distinct from) age, instructing lower courts to look for evidence of whether age actually motivated the decision (Crawshaw-Lewis, 1996). Although this decision concerned a pension status case, its reasoning has been applied to other age cases, and it has in some ways made plaintiff's cases more difficult by noting that decisions based on factors correlated with age were not necessarily sufficient to establish age discrimination. In particular, since Hazen the courts have been much less favorable to age discrimination disparate impact claims based on 
the argument that an employer's decision was motivated by the higher salary of an older worker, with some courts ruling that firing employees based on high compensation stemming from seniority does not violate the ADEA (Crawshaw-Lewis, 1996, p. 781).

\section{Rationale for Age Discrimination Legislation}

\section{A. Discrimination, Differential Treatment, and Worker Choice}

This section discusses the rationale for age discrimination legislation, examining both evidence of age discrimination and incentives for employers to discriminate based on age. These topics cannot be discussed, however, without confronting the issue of what is meant by "age discrimination." In the sense of the Becker model of discrimination, and much of the empirical work on race and sex discrimination, the operational definition is something akin to treating groups of workers (such as the old) differently in a way that cannot be explained by differences in productivity or characteristics related to productivity or costs. Such treatment is probably most easily interpreted as based on animus, although it could also be based on incorrect stereotypes, which, as noted earlier, is probably what was originally meant by the "arbitrary" age discrimination explicitly prohibited by the ADEA. However, employers may also engage in "differential treatment" based on age for reasons unrelated to animus or incorrect stereotypes, and interpreting whether such treatment is discriminatory is difficult. Indeed the case law recognizes the inevitable tension here, trying to distinguish between differential treatment based solely on age, and behavior based on factors that happen to be related to age but are not necessarily driven by age-related considerations per se, and additionally barring some types of behavior that might be justified on productivity or cost grounds, while allowing others. These distinctions set the stage for an expanded view of age discrimination beyond simple arbitrary discrimination, perhaps most commonly when an employer has an economic incentive to treat workers differentially because of age, yet cannot mount an adequate defense based on "reasonable factors other than age."

Empirically, of course, it is extremely difficult to distinguish between these different types of

behavior. The ensuing discussion, therefore, often refers to "differential treatment based on age," which 
may sometimes, but not always, reflect discrimination of the type outlawed by the ADEA. Alternatively, especially when discussing evidence from empirical tests, it sometimes refers to behavior or results “consistent with age discrimination," again to emphasize that it may or may not reflect actual discrimination based on either economic models or legal distinctions. Finally, another possibility that must sometimes be considered is whether a pattern of behavior consistent with differential treatment by employers instead reflects differences in workers' choices, which may of course vary with age.

\section{A. Evidence of Differential Treatment of Older Workers Prior to the ADEA}

Empirical tests for evidence consistent with age discrimination are far less numerous and at the same time more varied and less "direct" than are those relating to race or sex discrimination. There are most likely two reasons for this. First, research on age discrimination had and continues to have less urgency, because along many dimensions older workers are better off economically than other groups, and do not suffer the sizable pay differences associated with sex, and unemployment rate differences (and to a lesser extent pay differences) associated with race. Second, regression-based empirical methods for testing for race and sex discrimination, while potentially problematic, have a simple intuitive appeal and can be interpreted in light of the Becker model of employer discrimination (Neumark, 1988), because race or sex per se are not thought to affect productivity (although they may pick up unobserved productivity differences), and race, at least, is probably not thought to affect tastes for work vs. leisure. In contrast, such analyses may well be inappropriate for studying age discrimination, because age per se may affect productivity and tastes for leisure.

It is probably fair to say that there was a good deal of evidence consistent with age discrimination from the period prior to the ADEA. Two sets of facts were documented in the pre-ADEA period to make the case that older workers suffered from discrimination. The first concerned unemployment. Miller (1966) noted that while in general unemployment rates were highest for the youngest part of the population, there were also some indications that older workers who lost their jobs had a more difficult time finding new jobs than did "prime-age" workers. In particular, in 1963 the 
unemployment rate for men over age 55 was a full percentage point higher ( 4.5 percent) than for men aged 35-54 (3.5 percent). Perhaps more tellingly, durations of unemployment were longer for older men, with average durations of 21 weeks for men over age 45, compared with 14 weeks for men 45 and under. ${ }^{19}$ Furthermore, Miller suggests that unemployment comparisons may understate the problem, as older individuals who cannot find work are more likely to leave the labor force and hence not appear as unemployed. ${ }^{20}$ Finally, related to this, Miller cites survey evidence of hiring practices in various cities carried out just prior to the ADEA, which found that while workers over age 45 were 25 percent of the unemployed, they constituted only 8.6 percent of new hires. ${ }^{21}$

While such evidence is consistent with discrimination, it need not reflect discrimination. For example, in models of long-term incentive contracts (Lazear, 1979)-described in more detail belowolder workers are paid more than their marginal product on their "career" job, while workers at new jobs are paid considerably less than their marginal product. Thus, new employers would not pay older workers a wage as high as that earned on their previous job, which could lead older workers to search longer, finding more wage offers unacceptable. Similarly, in a model with specific human capital investment, older workers with high tenure will tend to be paid more than their best wage at an alternative employer. If reservation wages are formed partly on the basis of pre-displacement wages, the same result occurs (Valletta, 1991). Note, however, that both of these models predict that it is tenure, rather than age per se, that might increase the lengths of spells of joblessness. Although age and tenure are obviously related, their separate effects can be estimated. Valletta specifies a model for length of jobless spells of permanently displaced workers, allowing for nonlinear effects of age and tenure. While he finds that among men the highest-tenure workers have longer spells of joblessness-consistent with the

\footnotetext{
${ }^{19}$ Boglietti (1974) reports similar evidence for Canada and Western European countries in the 1960s and early 1970s.

${ }^{20}$ Unemployed workers are measured in the United States as those individuals who do not have a job but are looking for work.

${ }^{21}$ The evidence comes from a study by the U.S. Department of Labor (1965). This survey covered cities in states lacking anti-age discrimination statutes.
} 
above models-he also finds that lengths of jobless spells rise sharply for workers in their 50s and early 60s for all men and white-collar women. The strong age effects independent of tenure suggest that Lazear contract or specific human capital models do not fully explain the longer unemployment durations of older workers.

Shapiro and Sandell (1985) provide additional evidence of re-employment difficulties for displaced older workers. They use the National Longitudinal Survey of Older Men (NLSOM), covering the period 1966-1978, which predates the transfer of enforcement authority for the ADEA to the EEOC. They first choose a sample of involuntary job losers, and estimate a wage equation for the predisplacement job accounting for both age and tenure. They then use this estimated regression to predict wages on the post-displacement job, in the most relevant case accounting for the loss of tenure resulting from the job loss, and adjusting for age. Finally, they ask whether the gap between the predicted and actual wage on the subsequent job varies with age. The adjustments for age and tenure are important to control for other sources of larger wage losses among older men. Without the adjustment for tenure, the wage loss could be attributable to loss of specific human capital, which might be highest for the oldest workers. But with the adjustment for tenure, loss of specific human capital should not play a role. Similarly, adjusting for age should allow for depreciation of general human capital at older ages. The findings indicate that only men aged 65 and older appear to suffer disproportionate wage losses upon displacement. However, Shapiro and Sandell suggest that this is at best weak evidence of age discrimination because the sample from which they estimate the wage structure using pre-displacement wages only goes to age 63 , and therefore they are unable to control for the possibility of much sharper depreciation of human capital at ages 65 and beyond. ${ }^{22}$ They also note that pre-displacement wages may reflect the effects of discrimination, so that their evidence does not provide a general test for age discrimination, but rather for discrimination affecting displaced workers.

\footnotetext{
${ }^{22}$ One possibility they do not explore is that the Social Security earnings test leads workers aged 65 and over to choose lower wage jobs (presumably entailing less effort or hours). Johnson and Neumark (1996) present evidence consistent with this effect for older men.
} 
The second set of facts regarding age discrimination prior to the ADEA concerns age restrictions in hiring. Miller (1966) cites surveys conducted in New York in 1957 and 1958 in which 42 percent of firms had maximum age restrictions of 50 for new hires. A U.S. Department of Labor study found that in a survey conducted in five cities in states without anti-age discrimination statutes in 1965, nearly 60 percent of employers imposed upper age limitations (usually between age 45 and 55) on new hires (U.S. Department of Labor, 1965, cited in Hutchens, 1988). Clearly this evidence mitigates against the notion that higher and longer unemployment of older workers reflected solely worker choice.

Aside from this rather direct evidence of discriminatory practices, there is additional evidence of a quite different nature using data from the period following the passage of the original ADEA, but prior to more vigorous enforcement of the ADEA beginning in 1979, and hence to some extent informative about age discrimination prior to the ADEA as we now know it. Johnson and Neumark (1997) study data from the NLSOM for the period 1966-1980, focusing on self-reported age discrimination as captured in the question "During the past five years, do you feel that so far as work is concerned, you were discriminated against because of your age?" Longitudinal information on responses to this question, and on subsequent labor market behavior, is used to study the impact of age discrimination. ${ }^{23}$ They find, first, that only a relatively small percentage of older men reported age discrimination (seven percent of the sample). However, this refers only to men with jobs, and hence might not cover the type of discrimination in hiring posed by age restrictions on new hires (although it could do so partially if they had searched for other jobs). Second, they find that those workers who report discrimination are more likely to separate from their current employer, and less likely to be employed subsequently. In addition, those who report discrimination and separate from their employer suffer a wage loss on the order of 10 percent. Thus, this evidence points to other adverse consequences of differential treatment by age (as

\footnotetext{
${ }^{23}$ Johnson and Neumark focus on those individuals who switch from reporting no age discrimination to reporting age discrimination, to attempt to net out the effects of unobserved individual differences in the propensity to report discrimination that might be correlated with labor market behavior. They also control for general job satisfaction to account for other negative job characteristics that might cause a worker to report age discrimination.
} 
perceived by workers) in the period prior to EEOC enforcement of the ADEA.

In a different vein, Rosen and Jerdee (1977) conducted a study of employer behavior based on reactions to hypothetical scenarios regarding how managers would respond to various situations involving workers. ${ }^{24}$ Specifically, managers were given hypothetical scenarios regarding personnel decisions (covering, as examples, unsatisfactory performance, investment in training, and promotion), and asked how they would respond. However, for some survey respondents the worker involved was described as young (age 32), and for others the worker involved was described as old (age 61). The responses led the researchers to reach three main conclusions. First, managers perceive older workers as less flexible and more resistant to change. Second, managers are less inclined to provide support for career development and training of older workers. And third, promotion opportunities for older workers are more likely to be restricted in jobs requiring flexibility, creativity, and high motivation. Rosen and Jerdee suggest that these attitudes likely have real impacts in denying older workers opportunity, although their evidence does not speak to this directly.

\section{B. Employer Incentives for Differential Treatment based on Age}

The preceding evidence is certainly consistent with discrimination against older workers based on age. However, it does not tell us much about the source of the discriminatory behavior, which is of interest both from the perspective of the economist trying to understand behavior in the labor market and to analyze the need for legislation prohibiting age discrimination, and, as amply illustrated above, from the perspective of the law trying to establish what type of behavior is prohibited by the ADEA.

\section{B. 1. Animus}

The simplest hypothesis, perhaps, is that age discrimination is based on animus toward older workers. As explained by the Becker model of discrimination, in the case of animus toward a particular group on the part of an employer, that employer essentially has an economic incentive (defined over profits and tastes for employment of various types of workers) to discrimination against that group.

\footnotetext{
${ }^{24}$ See also Rosen and Jerdee (1976).
} 
Animus-based discrimination may generate inefficiencies at the economy-wide level, as human resources are not put to their most effective use (as long as we do not take account of discriminating employers' pernicious tastes in evaluating social welfare). ${ }^{25}$ As noted above, however, animus toward older workers was not the view of the original Department of Labor report (U.S. Department of Labor, 1965) arguing for passage of the ADEA, and it seems difficult to view age discrimination in the same light as race discrimination, for which there is a well-documented history of animus. Posner further points out that "the kind of "we-they" thinking that foster racial, ethnic, and sexual discrimination is unlikely to play a role in the treatment of the elderly worker" (1995, p. 320), because the people who make the firing and hiring decisions are often older individuals. In addition, Issacharoff and Worth Harris (1997) argue that the legislative history of the ADEA indicates that age discrimination was perceived to be quite different from and more complex than blind or arbitrary prejudice based on race, national origin, etc.

\section{B. 2. Stereotypes}

An alternative view that runs through the Department of Labor report is that employers hold negative stereotypes about older workers. Some of these were discussed above in the context of Rosen and Jerdee's (1977) work. Other research has documented stereotypes that discount the productivity and competence of older workers (e.g., Kite and Johnson, 1988). Employers holding negative stereotypes about older workers may perceive it in their interest to treat them differentially based solely on their age.

The use of stereotypes per se is well understood in economic models. In particular, when employers have imperfect information about productivity- or cost-related characteristics of workers, but know something about the average relationship between these characteristics and the groups to which workers belong (e.g., age, race, or sex), it is rational to use information on these group averages-which can be interpreted as stereotypes. This is referred to as statistical discrimination (Phelps, 1972). As Posner (1995, Ch. 13) argues, statistical discrimination may be an efficient way of processing information about workers or applicants, relative to other screening mechanisms.

${ }^{25}$ Holzer and Neumark (2000), in the context race and sex discrimination, discuss the conditions under which this type of discrimination generates inefficiencies. 
However, while reliance upon stereotypes that are "on average" correct can be efficient, incorrect stereotypes are more problematic. To the extent that these stereotypes are wrong, there is potentially a rationale for prohibitions of differential treatment of older individuals based on them. Indeed there are economic models in which government action to prohibit discrimination based on incorrect negative stereotypes can "correct" the false stereotypes, although the reverse can also occur (Coate and Loury, 1993).

While employers may hold negative stereotypes regarding older workers, some of which may be incorrect, all "generalizations" held about the consequences of aging are not necessarily false. What does the evidence say about negative stereotypes regarding older workers? Some earlier studies in the field of industrial gerontology explored the effects of aging on productivity or supervisor appraisals (which could reflect stereotypes), and found evidence of productivity either holding steady or declining slightly (see Meier and Kerr, 1976; Fleischer and Kaplan, 1980). Other evidence points to declines in acuteness of vision or hearing, ease of memorization, computational speed, etc. (see the evidence reviewed in Posner, 1995, Ch. 4). However, older workers may offset these declines with greater effort, and some faculties may increase with age, as others decrease. As an example, Posner (1995, Ch. 7) argues that aging is associated with declines in creativity but increases in leadership ability. Finally, some more recent evidence from production function estimates for the manufacturing sector fails to find evidence of lower productivity of workers aged 55 and older, who appear as productive as those aged 3554 and more productive than those under age 35 (Hellerstein, et al., 1999). ${ }^{26}$ Thus, the evidence is probably best characterized as mixed. Presumably, though, there is tremendous variation within age groups. With the evidence suggesting that many differences between older and younger workers are largely nonexistent or small, negative stereotypes about older workers and classifications based on them seem likely to act-at least sometimes-in an arbitrary fashion, harming many productive older workers.

\section{B. 3. Direct Economic Incentives}

${ }^{26}$ As Posner (1995) points out, all such evidence is potentially prone to upward selection bias in estimates of the productivity of older workers, if the most productive workers tend to remain on the job. 
Finally, there are plausible direct economic incentives for employers to treat workers differentially based on age. The simplest of these may be incentives based on relatively accurate stereotypes or generalizations. For example, as noted by Miller (1966), because of the higher likelihood of illness and death among older workers, costs of health insurance and life insurance are likely to be higher for older workers. Similarly, there may be less time over which to recoup an investment in training when hiring an older worker (although younger workers may be more likely to leave the firm for another job). In principle, the employer may be able to adjust the wage or compensation package to compensate for the differential costs. There may, though, be barriers to doing this stemming from the law or other issues of workforce management (precluding, for example, paying an older worker a lower wage than a younger worker, to compensate for higher health insurance premiums). It is not clear why the law should prohibit differential treatment based on these considerations, and in some cases it does not (see, e.g., the discussion of benefits in Section II.B).

A more complicated set of economic incentives and consequent issues for government policy comes from consideration of models of the long-term attachment of workers to employers in the context of providing incentives to workers to exert effort (and not to shirk). As developed by Lazear (1979), the basic model that captures these ideas has employers paying workers less than their marginal product when young, and more than their marginal product when old. The underpayment in the younger years, and the fact that the worker is never fully paid for his "lifetime" productivity until his retirement, provides an incentive for the worker to work hard and avoid losing his job.

The Lazear model creates three types of incentives pertinent to differential treatment of workers based on age. First, the model explains the existence of mandatory retirement. As Lazear shows, the overpayment of older workers entails older workers being paid more than the marginal value of their leisure, so they will not choose to retire at the date at which, over their lifetime, the stream of wage payments adds up to the stream of marginal productivity. This, Lazear argues, necessitates mandatory 
retirement. ${ }^{27}$ While workers are content with such long-term incentive contracts ex ante, ex post they would not voluntarily leave the firm, so that from the point of view of the older worker the imposition of an age at which the worker must leave the firm may appear discriminatory.

Second, as demonstrated theoretically by Hutchens (1986), Lazear-type contracts are likely to impose barriers to hiring older workers, in his model because these contracts likely impose some component of fixed costs that can be amortized only over a shorter period for older workers. Hutchens also presents evidence consistent with this conjecture. Barriers to paying new older workers much lower wages than current older workers can lead to the same result, as they make it impossible to bring in new older workers at wages initially below their marginal products. ${ }^{28}$

Third, Lazear contracts provide an incentive for the employer to behave "opportunistically," discharging workers unfairly (i.e., not for "shirking" as understood in the original implicit contract) before their retirement date, so as to pocket some of the difference between a worker's productivity and compensation to date. One argument against employers choosing to behave opportunistically is based on reputation effects; specifically, doing so once will damage or destroy the employer's ability to enter into similar long-term incentive contracts in the future. However, reputation effects require fairly strong conditions to work. One possible barrier, discussed in Neumark and Stock (1999), is that there is an information asymmetry between workers and firms, allowing firms to claim that layoffs of older workers are due to changed economic conditions, which workers cannot fully verify. ${ }^{29}$ In addition, institutional innovations may arise that allow employers to "circumvent" damages to reputation stemming from opportunistic behavior. For example, building on an argument originally made by Shleifer and Summers

\footnotetext{
${ }^{27}$ As noted above, this was ultimately prohibited by the ADEA. Lazear later showed that pension incentives could play a similar role (Lazear, 1995, Ch. 4).

${ }^{28}$ As Issacharoff and Worth Harris state, "because a reduction in pay to a level approximating productivity would appear to be a dignitary affront to the employee and would be potentially disruptive within the firm, the life-cycle wage pattern has the predictable effect of freezing unemployed older workers out of the job market altogether" (1997, p. 780).

${ }^{29}$ This argument has some similarities to that of Holmstrom (1981), although in a slightly different context.
} 
(1988), Gokhale, et al. (1995) provide evidence that hostile takeovers of corporations are associated with reductions in employment of more senior workers. The argument is that such abrogations of Lazear contracts can be carried out following the hostile takeover, and when the company is subsequently resold the new owner suffers no loss of reputation. Thus, on both theoretical and empirical grounds there appears to be reason to believe that incentives for opportunistic behavior remain.

In such a case, there are two potential arguments for legislation prohibiting age discrimination. First, as Neumark and Stock (1999) argue, such legislation may represent a "pre-commitment device" (Schelling, 1983), offering workers protection against opportunistic behavior by employers, and at the same time committing all employers to adhere to Lazear contracts, when it might be irrational and unconvincing for employers to make such commitments on their own. ${ }^{30}$ Second, there may be negative social externalities from employers reneging, as workers at other firms raise their subjective probabilities of their own employer reneging when they see other employers doing the same, leading to higher required compensation and less back loading of pay under Lazear contracts (Lazear and Moore, 1984).

This discussion of some of the direct incentives to treat workers differentially based on their age highlights the dependence of such incentives on the "correct" model of the age-earnings profile. For example, the Lazear model provides a basis for opportunistic behavior by employers against older workers as well as for mandatory retirement. Some of the same incentives are posed by "forced-saving" models of rising age-earnings profiles. In these models, a preference for rising consumption coupled with an inability to save-phenomena for which there is some evidence in the psychological literature-leads to workers preferring rising wage profiles as a forced-saving mechanism (Frank and Hutchens, 1993). ${ }^{31}$ Like in the Lazear model, this leads to wages that are below marginal product for new workers and most likely above marginal product for more senior workers (assuming that workers

\footnotetext{
${ }^{30}$ Jolls (1996) makes a related argument.
}

${ }^{31}$ This preference for upward-sloping wage profiles means that workers are willing to trade off present value of earnings for rising wages. Survey evidence consistent with willingness to accept this trade-off is reported in Loewenstein and Sicherman (1991). 
prefer wages that rise faster than marginal product). In contrast, a simple market-clearing model in which workers are always paid according to their current productivity (which is consistent with a rising age-earnings profile if there is general human capital investment) does not provide any economic basis for opportunistic discharges of older workers. Finally, in the original Becker model of specific human investment older workers are paid less than their marginal product, so, if anything, employers have particularly strong incentives to retain older workers. On the other hand, a modification of this model by Carmichael (1983) suggests that the reverse result may hold in a specific human capital model. Based on these considerations, to a large extent we would have to conclude that evidence against the "constantmarket-clearing" model, and in particular in favor of Lazear contracts or forced saving, would provide a more solid basis for suspecting that employers face economic incentives to treat workers differentially based on age.

The economics literature testing alternative models of the age-earnings profile is too vast to be reviewed here, but some general comments and examples of findings are in order. To date, research has yielded some evidence consistent with each of the alternatives. For example, Neumark (1995) reports evidence consistent with the forced-saving model. In particular, individuals with a demonstrated preference for forced saving-in the form of overpayment of income taxes during the year-are on steeper age-earnings profiles. There is also evidence consistent with the Lazear model. As an example, Hutchens (1986) constructs an index for industry-occupation pairs measuring the hiring of older workers relative to employment of older workers. Thus, lower values of the index indicate jobs that tend to employ but not hire older workers. Hutchens reports that the index is negatively related to job characteristics associated with Lazear contracts, such as pensions and mandatory retirement, indicating that in such jobs hiring of older workers is suppressed. At the same time, there is evidence consistent with wages rising lock-step with productivity, as in the general human capital model. Specifically, Hellerstein, et al. (1999) use matched employee-employer data for U.S. manufacturing to estimate establishment-level wage equations and production functions, and find that productivity differentials by 
age are closely reflected in wage differentials by age. And Neumark and Taubman (1995) find that key characteristics of earnings profiles are most consistent with the general human capital model.

The mixed evidence is not necessarily problematic. First of all, as this brief review suggests, researchers have brought to bear very different types of evidence, and it may require a good deal more research until a consensus emerges both on which types of evidence are most convincing, and what the evidence actually says. Second, this is not necessarily an either/or proposition. Elements of each model may help to explain rising age-earnings profiles. Viewed in this way, the important point is that some evidence exists that contradicts the spot market view of the labor market, and provides evidence of wages that are higher than marginal product for older workers. As long as this empirical characterization is correct-whatever the relative importance of alternative sources of upward-sloping profiles-there are some incentives for employers to treat older workers differentially based on their age.

\section{$\underline{\text { V. Empirical Evidence on the Effects of Age Discrimination Legislation }}$}

The effectiveness of age discrimination legislation in the United States and elsewhere has not been widely researched. Nonetheless, there is a small base of research on which to draw in order to reach some provisional conclusions. The evidence is of three types. First, there is some direct evidence on the effects of age discrimination legislation on labor market outcomes, which can tell us whether the legislation is having at least some of its intended effects. Second, there is empirical research on the existence of evidence consistent with age discrimination in the post-ADEA regime. Finally, there is evidence bearing on some central critiques of the ADEA. This evidence is described below, and summarized in Table 5 .

\section{A. Direct Evidence}

The direct evidence on age discrimination legislation simply tries to ascertain the direction and magnitudes of the effects of the legislation on labor market outcomes that ought to be affected. This can be viewed as asking whether the legislation has some of its intended effects, without speaking to the much more difficult question of the welfare implications or the "optimal" level or type of anti- 
discrimination effort.

Neumark and Stock (1999) studied the effects of age discrimination by exploiting the existence of anti-discrimination statutes in some states prior to the ADEA. Specifically, they look at changes in employment rates of older workers (in the protected age group) relative to younger workers. The state statutes are helpful because otherwise it is impossible to disentangle the effects of federal legislation from other time-series changes. If the only policy variation is the advent of federal legislation, then a change in relative employment of older workers when the ADEA passes, or when its enforcement was assigned to the EEOC, could be attributable to other changes over time in factors influencing the relative employment of older workers. This is a legitimate concern because the 1970s and first half of the 1980s witnessed sharp changes (declines, in fact) in relative employment and labor force participation rates of older individuals, with factors such as social insurance programs (Social Security), pension plan offerings, and health receiving considerable attention as possible explanations (e.g., Lumsdaine and Mitchell, 1999). With the state statutes, though, the advent of federal legislation can be separately identified by using the states that already had an anti-age discrimination statute to control for other aggregate changes in relative employment of older individuals, and using only the relative difference between these states and the other ("treatment") states to identify the effect of the policy change. In addition, of course, because the state statutes are implemented at different times, their direct effects can be estimated to draw stronger inferences regarding the effects of age discrimination legislation.

Using Census data from 1940, 1950, 1960, 1970, and 1980, and treating the federal law as binding or enforced only after the 1979 amendments, Neumark and Stock find that age discrimination laws boost employment rates of protected workers under age 60 by a small amount (.008, or eight-tenths of a percentage point), but boost employment rates of protected workers age 60 and over by a substantially higher .06 , or six percentage points. The estimates of the state-level age discrimination statutes in isolation are of a similar or slightly larger magnitude.

An additional important component of the ADEA is its prohibition of mandatory retirement. 
Neumark and Stock attempt to apply the same strategy to estimating the effects of the prohibition of mandatory retirement. However, because they do not focus on the very oldest workers, and because few states banned mandatory retirement prior to the federal legislation, they have very limited information on the basis of which to estimate the effects of banning mandatory retirement. They do not find statistically significant evidence that banning mandatory retirement boosted employment of older workers. This may be because the data are uninformative, or it may arise because employers are able to induce retirement at given ages even without mandatory retirement (Lazear, 1995).

In recent work, Adams (2000, Ch. 3) repeats this type of analysis using variation in state antidiscrimination laws from 1964 to 1967, when a number of states enacted anti-discrimination laws. Using essentially the same empirical strategy, and data from the Current Population Survey, Adams finds that age discrimination laws boosted employment of protected workers aged 60 and over by about .056 , or 5.6 percentage points, very close to the Neumark and Stock estimates.

Adams also takes the analysis further, estimating the effects of age discrimination laws on new hires. He first argues that the direction of effects of anti-age discrimination statutes is ambiguous a priori. On the one hand, these laws should reduce hiring discrimination, and hence boost hiring of older workers. On the other hand, if older workers are retained longer because of age discrimination legislation, hiring of (other) older workers may fall. Similarly, anti-age discrimination legislation could strengthen long-term commitments between workers and firms, or simply increase the cost of hiring older workers, hence generating a preference for hiring younger workers and reducing hiring of older workers. Given that the CPS surveys Adams uses do not have tenure data, he uses two methods to classify new hires, acknowledging that neither is perfect. The first is based on workers who are employed at the time of the survey, but report some period of non-employment during the prior year, while the second requires that the person who had some non-employment also searched for work in the prior year (which is meant to remove from the group of new hires those who returned to the same job). Unfortunately, these measures fail to pick up workers who started a new job without an intervening spell of non-employment. 
Using essentially the same empirical strategy as for the analysis of employment effects, Adams find little evidence of effects of age discrimination laws on the relative probability that an older worker is a new hire, with the possible exception of some evidence indicating a reduced probability for 65-70 year-olds. Clearly, though, there is no evidence of a positive effect on hiring.

Finally, the positive employment effect, coupled with no evidence of a positive effect on hiring, suggests that age discrimination laws boost retention of older workers. Curiously, though, Adams finds that these laws increase the relative probability that older workers exit employment. How can this puzzle be resolved? In his final analysis, Adams finds that age discrimination laws are associated with substantial reductions in retirement among older workers. Thus, more of them are remaining in the labor force, and even though hiring probabilities may worsen slightly and the probability that an employed worker is retained falls, the reduction in retirement leads to a net increase in employment.

A recent study of faculty retirement by Ashenfelter and Card (2000) provides perhaps the best evidence to date on the effects of eliminating mandatory retirement, although the evidence is limited to a single, narrow occupation-university professors. The authors do a before and after comparison based on the elimination of mandatory retirement for professors under federal law, an earlier cross-sectional comparison of institutions a subset of which had no mandatory retirement because of state law, and a pooled analysis allowing for a richer comparison. The findings are quite striking, as both the state and federal "uncapping" of mandatory retirement appear to lead to large drops in retirement at ages 70 and 71 , and concomitant large increases in the proportion of 70-year-old faculty that are teaching two years later. This evidence may differ from that reported above (in Neumark and Stock, 1999), simply because it is based on more informative data. In addition, however, professors are typically on defined contribution pension plans, which sharply limit the ability of the employer to create financial inducements to retire at particular ages. In contrast, Lazear (1995) showed that employers could restructure defined benefit plans to induce retirement at desired ages. ${ }^{32}$ Thus, with defined benefit plans

\footnotetext{
${ }^{32}$ Defined benefit pension plans specify pension payments based on a formula involving salary near the end of the career and years of service. Defined contribution plans are based on payments by
} 
mandatory retirement may have much weaker effects on labor force participation and employment of older workers. In addition, the academic profession may be quite unique, in part because the job is not physically demanding. Indeed earlier research considering more general samples, by Burkhauser and Quinn (1983) and Fields and Mitchell (1984), presented evidence suggesting weak impacts of mandatory retirement.

\section{B. Continuing Evidence of Differential Treatment Based on Age}

Another avenue of research that can be viewed as assessing the effectiveness of the ADEA consists of attempts to test for evidence consistent with age discrimination in the period following passage of the ADEA. The continued existence of such evidence following the ADEA does not necessarily imply failure of the law. Anti-discrimination legislation presumably never aims to eliminate all discrimination, but just to root out and deter much of it and the most egregious and costly cases; as an example of this, anti-discrimination laws have typically not applied to the smallest employers. In addition, as described above, age discrimination law has undergone quite a few changes strengthening its provisions, so continuing evidence consistent with discrimination in the period following its initial implementation but preceding its current form would not necessarily speak to the effectiveness of current law. On the other hand, there is a fairly large hole in our knowledge regarding the effectiveness of age discrimination legislation. In particular, there is no systematic attempt using comparable data over time to conduct and compare tests or measurements of the evidence relating to age discrimination before and after the ADEA. This contrasts quite sharply with the literature on race and sex discrimination (see, e.g., Blau, 1998; Eberts and Stone, 1985; Smith and Welch, 1977).

Building on his earlier work, Hutchens (1988) develops "segregation curves" used for contrasting distributions of workers across industries and occupations. His analysis of 1983 Current Population Survey data shows that newly hired older workers are clustered in a smaller set of industries and occupations than are newly hired younger workers or all older workers. The potential reasons for this

employers into investment funds, which upon retirement form the basis of the pension. 
include all of the possible bases for differential treatment based on age that were discussed above. In addition, though, the evidence Hutchens presents-as he acknowledges-cannot rule out a role for preferences among older workers taking new jobs for a narrower set of jobs. However, Hutchens argues that coupled with other evidence-including larger wage losses of displaced older workers, longer spells of unemployment, and the existence of upper age limits prior to the enactment of laws barring age discrimination-this clustering likely reflects discrimination. ${ }^{33}$

On the other hand, Hirsch, et al. (2000) present some evidence that those occupations that appear more closed to older new hires have steeper experience profiles and higher prevalence of pensions, evidence that suggests that the exclusion of new older workers may be based more on considerations arising from Lazear contracts. They also report only slight improvement over time in the occupational segregation facing new hires among older workers, and hence are reluctant to conclude that the problem is declining in importance.

While the research just described focuses on hiring, attention in the late 1980s and the 1990s in the United States focused on involuntary job terminations, as corporations restructured and implemented layoffs (see, e.g., Cappelli, 2000). Although much of this research was contentious (see Neumark, 2000, for a thorough review), one piece of fairly unambiguous evidence was increased involuntary terminations of more-tenured workers (Polsky, 1999). Although this evidence has not been viewed through the prism of age discrimination, it is potentially consistent with an increased tendency to treat workers differentially based on age.

${ }^{33}$ Garen, et al. (1996) present a model in which tax rules requiring equal fringe benefits coupled with age discrimination laws barring lower wage payments to older workers deter hiring older workers when defined benefit pension plans are used. This occurs because firms want to structure pensions to reduce turnover (presumably because of training), but because reducing turnover is not an issue for older hires, pension costs are effectively higher for them. At the same time, age discrimination laws preclude employers from paying lower wages to older workers to compensate for the higher benefit costs. They also find some evidence consistent with this conjecture, as more generous defined benefit plans are associated with reduced employment prospects for older workers. This then offers an alternative explanation for Hutchens' evidence, and may point to some negative effects of age discrimination laws, although any source of wage constraints-not just the age discrimination laws-could generate the findings in Garen, et al. 
Finally, Adams (2000, Ch. 2) revisits the approach of using self-reported measures of age discrimination. He uses data from the 1992 and 1994 waves of the Health and Retirement Study, which includes a question about whether workers believe that their employer gives preference to younger workers in promotion. Although repeated observations on this question are not available, Adams is able to include information on the perceived work environment and fairness of one's pay to try to control for other negative aspects of the workplace that might not be related to age discrimination, but which workers might otherwise "blame" on discrimination once asked. He finds no wage differential associated with reported age discrimination. However, he does find evidence that reported age discrimination is associated with lower wage growth across the two waves, and with a reduced expectation of working at age 62 or 65 , consistent with deleterious effects of age discrimination..$^{34,35}$

\section{C. Critiques of the ADEA}

The evidence regarding direct effects of the ADEA points to some positive impacts on older individuals and workers. This evidence bears on one of the simpler but potentially important critiques of the ADEA. In particular, Posner (1995, Ch. 13) argues that the ADEA acts to reduce hiring of older workers, for two reasons. First, according to Posner, the costs of hiring these workers are increased as a result of their new legal rights under the ADEA. Second, because damages in hiring discrimination cases are likely to be small, while injunctive relief-hiring the older worker who has filed a claim-is unlikely to be attractive to a plaintiff, legal action is unlikely to be effective in increasing hiring of older workers. The evidence on the effects of the ADEA on employment and hiring of older individuals does not point to increased hiring; rather, if anything, it points to slightly reduced hiring, consistent with this critique. Overall, though, the evidence points to increased employment of older individuals. This suggests that

\footnotetext{
${ }^{34}$ With only the two waves of the HRS, Adams' ability to track actual retirement is limited.

${ }^{35}$ Herz and Rones (1989) report results of a Gallup survey conducted in 1985, in which six
} percent of workers aged 40 and over reported that they had experienced age discrimination, mostly in the form of being denied a promotion or chance for advancement based on age. Although not directly comparable, this six percent figure is close to the seven percent figure reported in Johnson and Neumark (1997) for an earlier period. Because these figures are based on workers, they are not very useful in trying to gauge the overall extent of age discrimination. 
while the ADEA may have proven somewhat ineffective in addressing the behavior that was most often cited in justifying it-namely hiring discrimination-it nonetheless had positive impacts on older individuals in light of which it must be evaluated.

A significantly harsher critique of the ADEA is that rather than furthering any antidiscriminatory goals, the ADEA acts largely to provide a windfall to older workers. Such an interpretation is not directly contradicted by evidence that age discrimination legislation boosts employment of older workers. The original argument espousing this view of the ADEA was proffered by Lazear (1979). After developing the argument that mandatory retirement was part of an efficient longterm incentive contract, and acceptable ex ante-although not ex post-to older workers, Lazear criticizes the elimination of mandatory retirement. Because in his model older workers earn more than the value of their leisure at the time of retirement, it is in their interest to eliminate mandatory retirement. Yet doing so would also, Lazear argued, impair the ability of workers and firms to enter into Lazear-type contracts. Thus, he concludes, upon eliminating mandatory retirement "current older workers will enjoy a small once-and-for-all gain at the expense of a much larger and continuing efficiency loss that affects all workers and firms adversely" (Lazear, 1979, pp. 1283-4).

In retrospect, this perspective on the effect of eliminating mandatory retirement may have been too pessimistic. First, subsequent empirical work has concluded that firms have largely been able to offer financial incentives to induce retirement at specific ages (e.g., Burkhauser and Quinn, 1983; Fields and Mitchell, 1984). Second, Lazear's later work (1982) showed that pensions whose value varied with age could have incentives structured to induce retirement at specific ages, consistent with this evidence. On the other hand, the Ashenfelter and Card study cited above suggests that in at least some settings-perhaps those with defined contribution benefit plans-the elimination of mandatory retirement does lead to later retirement.

Some criticism of the ADEA has gone well beyond Lazear's specific focus on mandatory retirement, and argued that the entire structure of anti-age discrimination legislation reflects rent-seeking 
behavior on the part of older workers. This argument is put forth forcefully by Issacharoff and Worth Harris (1997). First, they argue that the original intent of Congress in passing the ADEA was to eliminate the kind of discrimination that was reflected in maximum age limits for new hires (p. 793). In contrast, citing evidence in Schuster and Miller (1984), they note that the typical ADEA plaintiff is seeking redress over dismissal (discharge or involuntary retirement), not discrimination in hiring; see also Table $3 .{ }^{36}$ Based on this evidence, and evidence on the race of complainants, they argue that the ADEA has largely become a form of protection against wrongful discharge for older white males, a form of protection that does not generally exist in the United States (p. 796). ${ }^{37}$

It is a bit difficult to provide a full assessment of this critique. There seems little doubt that the AARP has successfully lobbied for legislation that benefits older workers, without necessarily (or intentionally) advancing overall welfare. However, it is not necessarily the case that the prevalence of discharges among ADEA claims implies that the ADEA is best characterized as rent seeking. First, Issacharoff and Worth Harris note that refusal to hire cases are more difficult to prove, and, as was already noted, Posner argues that damages in hiring cases are not likely to be large. But the most egregious hiring discrimination cases may nonetheless surface. Second, and potentially more important, the prevalence of discharge cases may reflect employers opportunistically reneging on Lazear contracts. Issacharoff and Worth Harris are aware of the incentive for opportunism, but dismiss the ADEA as an appropriate way to combat this, arguing that "If the source of the risk to older workers is economics, in general, and opportunistic breaches, in particular, a real question emerges as to why this problem should be folded into the antidiscrimination rubric" (p. 800). As a matter of how well this rationale coincides with the original intent of the ADEA, this may be a valid point. But it is unclear how it is relevant to

\footnotetext{
${ }^{36}$ Schuster and Miller do not have a sample of discrimination charges. Rather, they focus only on court cases, using a LEXIS search. They then select a small subset of cases that were decided on substantive matters; a much higher proportion were decided on procedural issues. Posner (1995, Ch. 13) presents similar evidence.

${ }^{37}$ Issacharoff and Worth Harris further elaborate on the role of the American Association of Retired Persons (AARP) in lobbying for amendments to the ADEA and other legislation that benefitted older workers, attempting to identify the "agent" of the rent-seeking or capture theory of the ADEA.
} 
policy or to the ADEA as it has evolved through case law. There is a policy argument for legislation that prevents this type of opportunistic behavior, and the case law seems to clearly recognize this. ${ }^{38}$

Aside from these considerations, Neumark and Stock (1999) have implemented an empirical test of the consequences of age discrimination legislation, in addition to their analysis of employment effects that was described above. In particular, they argue that if age discrimination laws acted predominantly as rent-seeking devices for older workers, their passage would reduce the use of long-term incentive (Lazear-type) contracts for new labor market entrants. On the other hand, if the predominant effect was to strengthen such contracts by reducing opportunistic behavior on the part of employers, the use of such contracts would be reinforced. Empirically, they test these two alternative views by asking whether age discrimination laws result in flatter or steeper age-earnings profiles of new entrants, with the former corresponding to the rent-seeking hypothesis, and vice versa. The evidence points quite unambiguously toward the hypothesis that the predominant effect of age discrimination legislation is to strengthen longterm incentive contracts, as age-earnings profiles steepen following the passage of age discrimination laws. This does not mean that age discrimination legislation does not entail some rents appropriated by older workers, but rather that the main effect is to strengthen the ability of workers and firms to enter into long-term incentive contracts. This evidence therefore contradicts the assertion of Issacharoff and Worth Harris that "the ADEA's casual introduction of the antidiscrimination norm into the career-wage relationship has significantly damaged the life-cycle arrangement” (1997, p. 823). While there may be something to the rent-seeking critique of the ADEA, rent-seeking does not appear to be the best characterization of the overall effects of the legislation.

\section{Conclusions}

The United States has a history of legislation prohibiting age discrimination covering more than 30 years. In that period, age discrimination legislation has grown into a nearly equal partner with

\footnotetext{
${ }^{38}$ The authors do, however, suggest some alternatives, based on either abrogating or limiting employment at will, creating compulsory arbitration in cases of termination of long-term employees, or other adminstrative mechanisms (pp. 800-1).
} 
legislation barring discrimination based on race and sex, although it has attracted less political debate. It is difficult to come up with a single overall assessment of the U.S. experience with age discrimination legislation, but the following points emerge from the existing literature and evidence:

- Prior to the enactment of the ADEA, there was ample evidence consistent with hiring discrimination against older workers. Evidence of other types of discrimination is difficult to ascertain, but some research points to suggestive evidence of discrimination in promotions, training, etc.

- Differential treatment based on age is probably not based on animus, and as such differs from discrimination based on race and possibly sex. Negative stereotypes of older workers may in part explain differential treatment, as may economic motives for employers to classify and treat workers differently based on age. In all cases some rationale can be offered for government intervention to prohibit or reduce this differential treatment. On the other hand, the valid economic motives employers may have for classifying and treating workers based on their age raise some concerns about possible efficiency costs of age discrimination legislation.

- Age discrimination legislation at both the state and federal level boosts relative employment of older workers, and reduces retirement of older individuals.

- In the post-ADEA period, there is still evidence consistent with age discrimination impacting the occupations into which older workers get hired, and their opportunities for wage growth.

- Age discrimination legislation can be interpreted as rent-seeking behavior by older workers, and some of the political history of the legislation is consistent with this. However, the empirical 
evidence suggests that the predominant effect of age discrimination legislation has been to reduce the likelihood that firms renege on long-term commitments to older, higher-paid workers, and consequently to strengthen long-term relationships between workers and firms.

Based on these conclusions, a relatively positive assessment of age discrimination legislation in the United States is more warranted than a negative assessment. However, there is not a sufficiently overwhelming amount of evidence and variety of tests to think that the existing body of research is decisive. In many cases, there are only one or two studies that address a particular question. This contrasts sharply with the vast quantity of research on many other public policy issues in the United States, and should give the reader pause in drawing overly strong conclusions based on our current knowledge. 


\section{$\underline{\text { References }}$}

Adams, Scott J. 2000. "Three Essays on the Economics of Aging," Ph.D. Dissertation, Department of Economics, Michigan State University.

Albert, Rory J., and Neal S. Schelberg. 1989. "Benefit Plans Redefined under ADEA.” Pension World, October, pp. 45-48.

Ashenfelter, Orley, and David Card. 2000. "How Did the Elimination of Mandatory Retirement Affect Faculty Retirement?" Working Paper No. 448, Princeton University, Industrial Relations Section.

Blau, Francine D. 1998. "Trends in the Well-Being of American Women, 1970-1995." Journal of Economic Literature, Vol. 36, No. 1, March, pp. 112-65.

Boglietti, G. 1974. "Discrimination Against Older Workers and the Promotion of Equality of Opportunity.” International Labour Review, Vol. 110, No. 4, October, pp. 351-65.

Burkhauser, Richard V., and Joseph F. Quinn. 1983. "Is Mandatory Retirement Overrated? Evidence from the 1970s." Journal of Human Resources, Vol. 18, No. 3, Summer, pp. 337-58.

Cappelli, Peter. 2000. "Examining the Incidence of Downsizing and Its Effect on Establishment Performance." In David Neumark, Ed. On The Job: Is Long-Term Employment a Thing of the Past (New York: Russell Sage Foundation), pp. 463-516.

Carmichael, Lorne H. 1983. "Firm-Specific Human Capital and Promotion Ladders." Bell Journal of Economics, Vol. 14, Spring, pp. 251-8.

Coate, Stephen, and Glenn C. Loury. 1993. "Will Affirmative-Action Policies Eliminate Negative Stereotypes?” American Economic Review, Vol. 83, No. 5, pp. 1220-40.

Crawshaw-Lewis, Stacey. 1996. "'Overpaid" Older Workers and the Age Discrimination in Employment Act.” Washington Law Review, Vol. 71, No. 3, July, pp. 769-96.

Eberts, Randall W., and Joe A. Stone. 1985. "Male-Female Differences in Promotions: EEO in Public Education.” Journal of Human Resources, Vol. 20, No. 4, pp. 504-21.

Fields, Gary S., and Olivia S. Mitchell. 1994. "Economic Determinants of the Optimal Retirement Age: An Empirical Investigation.” Journal of Human Resources, Vol. 19, No. 2, Spring, pp. 245-62.

Fleischer, Dorothy, and Barbara H. Kaplan. 1980. Work and Retirement: Policy Issues (Los Angeles: University of Southern California Press).

Frank, Robert H., and Robert M. Hutchens. 1993. "Wages, Seniority, and the Demand for Rising Consumption Profiles.” Economic Journal, Vol. 21, No. 3, August, pp. 251-76.

Friedman, Lawrence M. 1984. Your Time Will Come: The Law of Age Discrimination and Mandatory Retirement (New York: Russell Sage Foundation).

Garen, John, Mark Berger, and Frank Scott. 1996. "Pensions, Non-Discrimination Policies, and the Employment of Older Workers." Quarterly Review of Economics and Finance, Vol. 36, No. 4, Winter, pp. 417-30. 
Gokhale, Jagadeesh, Erica L. Groshen, and David Neumark. 1995. "Do Hostile Takeovers Reduce Extramarginal Wage Payments?" Review of Economics and Statistics, Vol. 77, No. 3, August, pp. 47085.

Hellerstein, Judith K., and David Neumark. 1995. "Are Earnings Profiles Steeper than Productivity Profiles? Evidence from Israeli Firm-Level Data." Journal of Human Resources, Vol. 30, No. 1, Winter, pp. 89-112.

Hellerstein, Judith K., David Neumark, and Kenneth R. Troske. 1999. "Wages, Productivity, and Worker Characteristics: Evidence from Plant-Level Production Functions and Wage Equations." Journal of Labor Economics, Vol. 17, No. 3, July, pp. 409-46.

Herz, Diane E., and Philip L. Rones. 1989. "Institutional Barriers to Employment of Older Workers." Monthly Labor Review, April, pp. 14-21.

Hirsch, Barry T., David A. Macpherson, and Melissa A. Hardy. 2000. "Occupational Age Structure and Access for Older Workers.” Industrial and Labor Relations Review, Vol. 53, No. 3, April, pp. 401-18.

Holmstrom, Bengt. 1981. "Contractual Models of the Labor Market.” American Economic Review Papers and Proceedings, Vol. 71, No. 2, May, pp. 308-13.

Holzer, Harry, and David Neumark. 2000. "Assessing Affirmative Action.” Journal of Economic Literature, Vol. 38, No. 3, September, pp. 483-568.

Hutchens, Robert M. 1996. "Delayed Payment Contracts and a Firm's Propensity to Hire Older Workers.” Journal of Labor Economics, Vol. 4, No. 4, October, pp. 439-57.

Hutchens, Robert M. 1988. “Do Job Opportunities Decline with Age?” Industrial and Labor Relations Review, Vol. 42, No. 1, October, pp. 89-99.

Issacharoff, Samuel, and Erica Worth Harris. 1997. "Is Age Discrimination Really Age Discrimination?: The ADEA's Unnatural Solution." New York University Law Review, Vol. 72, No. 4, October, pp. 780840.

Johnson, Richard W., and David Neumark. 1996. "Wage Declines among Older Men.” Review of Economics and Statistics, Vol. 78, No. 4, November, pp. 740-8.

Johnson, Richard W., and David Neumark. 1997. "Age Discrimination, Job Separations, and Employment Status of Older Workers." Journal of Human Resources, Vol. 32, No. 4, Fall, pp. 779-811.

Jolls, Christine. 1996. "Hands-Tying and the Age Discrimination in Employment Act." Texas Law Review, Vol. 74, June, pp. 1813-46.

Kite, Mary E., and Blair T. Johnson. 1988. "Attitudes Towards Older and Younger Adults: A MetaAnalysis.” Psychology and Aging, Vol. 3, No. 3, pp. 233-44.

Lazear, Edward P. 1979. "Why Is There Mandatory Retirement?” Journal of Political Economy, Vol. 87, No. 6, December, pp. 1261-84.

Lazear, Edward P. 1982. "Severance Pay, Pensions, and Efficient Mobility." NBER Working Paper No. 854.

Lazear, Edward P. 1995. Personnel Economics (Cambridge, MA: MIT Press). 
Lazear, Edward P., and Robert L. Moore. 1984. "Incentives, Productivity, and Labor Contracts." Quarterly Journal of Economics, Vol. 99, No. 2, May, pp. 275-96.

Lindemann Schlei, Barbara, and Paul Grossman. 1983. Employment Discrimination Law (Washington, DC: Bureau of National Affairs).

Lockard, Duane. 1968. Toward Equal Opportunity: A Study of State and Local Anti-discrimination Laws (New York: Macmillan).

Loewenstein, George, and Nachum Sicherman. 1991. "Do Workers Prefer Increasing Wage Profiles?" Journal of Labor Economics, Vol. 9, No. 1, January, pp. 67-84.

Lumsdaine, Robin L., and Olivia S. Mitchell. 1999. "New Developments in the Economic Analysis of Retirement." In Orley Ashenfelter and David Card, Eds. Handbook of Labor Economics, Vol. 3C (Amsterdam: Elsevier), pp. 3261-307.

Meier, Elizabeth L., and Elizabeth A. Kerr. 1976. "Capabilities of Middle-Aged and Older Workers: A Survey of the Literature.” Industrial Gerontology, Vol. 3, No. 3, pp. 147-56.

Miller, David. 1966. "Age Discrimination in Employment: The Problem of the Older Worker." New York University Law Review, Vol. 41, April, pp. 383-424.

Neumark, David. 1988. "Employers' Discriminatory Behavior and the Estimation of Wage Discrimination.” Journal of Human Resources, Vol. 23, No. 3, Summer, pp. 279-95.

Neumark, David. 1995. “Are Rising Earnings Profiles a Forced-Saving Mechanism?” Economic Journal, Vol. 105, No. 428, January, pp. 95-106.

Neumark, David (Ed.). 2000. On The Job: Is Long-Term Employment a Thing of the Past (New York: Russell Sage Foundation).

Neumark, David, and Wendy A. Stock. 1999. "Age Discrimination Laws and Labor Market Efficiency." Journal of Political Economy, Vol. 107, No. 5, October, pp. 1081-125.

Neumark, David, and Wendy A. Stock. 2000. "The Effects of Race and Sex Discrimination Laws." Unpublished paper, Public Policy Institute of California.

Neumark, David, and Paul Taubman. 1995. "Why Do Wage Profiles Slope Upward? Tests of the General Human Capital Model.” Journal of Labor Economics, Vol. 13, No. 4, October, pp. 736-61.

Phelps, Edmund S. 1972. "The Statistical Theory of Racism and Sexism.” American Economic Review, Vol. 62, No. 4, September, pp. 659-61.

Piette, Michael J. 1995. "Economic and Statistical Considerations In Analyzing Allegations of Age Discrimination.” Journal of Forensic Economics, Vol. 8, No. 2, Spring-Summer, pp. 139-57.

Polsky, Daniel. 1999. "Changing Consequences of Job Separation in the United States." Industrial and Labor Relations Review, Vol. 52, No. 4, July, pp. 565-80.

Posner, Richard A. 1995. Aging and Old Age (Chicago: University of Chicago Press).

Rosen, Benson, and Thomas H. Jerdee. 1976. “The Nature of Job-Related Age Stereotypes.” Journal of 
Applied Psychology, Vol. 61, No. 2, April, pp. 180-183.

Rosen, Benson, and Thomas H. Jerdee. 1977. “Too Old or Not Too Old?” Harvard Business Review, Vol. 55, No. 6, November-December, pp. 97-106.

Schelling, Thomas C. 1983. "Ethics, Law, and the Exercise of Self-Command." In Sterling M. McMurrin, Ed. The Tanner Lectures on Human Values, Vol. 4 (Salt Lake City: University of Utah Press).

Schuster, Michael, and Christopher S. Miller. 1984. "An Empirical Assessment of the Age Discrimination in Employment Act." Industrial and Labor Relations Review, Vol. 38, No. 1, October, pp. 64-74.

Shapiro, David, and Steven H. Sandell. 1985. "Age Discrimination in Wages and Displaced Older Men." Southern Economic Journal, Vol. 52, No. 1, July, pp. 90-102.

Shleifer, Andrei, and Lawrence H. Summers. 1988. "Breach of Trust in Hostile Takeovers." In Alan J. Auerbach, Ed. Corporate Takeovers: Causes and Consequences (Chicago: University of Chicago Press).

Smith, James P., and Finis Welch. 1977. "Black-White Wage Ratios: 1960-70.” American Economic Review, Vol. 67, No. 3, June, pp. 232-38.

Starkman, Paul E. 1992. "Alleging a "Pattern or Practice" Under ADEA: An Analysis of the Impact and Problems of Proof.” The Labor Lawyer, Vol. 8, No. 1, Winter, pp. 91-123.

Stone, Julia E. 1980. “Age Discrimination in Employment Act: A Review of Recent Changes.” Monthly Labor Review, Vol. 103, No. 3, March, pp. 32-6.

U.S. Department of Labor. 1965. The Older American Worker (Washington: Government Printing Office).

Valletta, Robert G. 1991. "Job Tenure and Joblessness of Displaced Workers.” Journal of Human Resources, Vol. 26, No. 4, Fall, pp. 726-41. 
Table 1: Key Federal Age Discrimination Legislation

\begin{tabular}{|l|l|l|}
\hline Year & \multicolumn{1}{|c|}{ Legislation } & \multicolumn{1}{c|}{ Provisions } \\
\hline 1967 & $\begin{array}{l}\text { Age Discrimination in } \\
\text { Employment Act (ADEA) }\end{array}$ & $\begin{array}{l}\text { Prohibited discrimination based on age, covering those } \\
\text { aged 40-65, including discrimination based on age } \\
\text { within this protected age range. }\end{array}$ \\
\hline 1975 & Age Discrimination Act & $\begin{array}{l}\text { Prohibited age discrimination in all programs or } \\
\text { activities receiving federal assistance, including state } \\
\text { or local government units that receive federal funds. }\end{array}$ \\
\hline 1978 & ADEA amendments & $\begin{array}{l}\text { Extended the age range for the protected group to 40- } \\
70, \text { raising the mandatory retirement age to 70 in the } \\
\text { process. Eliminated mandatory retirement for most } \\
\text { federal employees. Granted some exemptions or } \\
\text { delays for raising mandatory retirement age. }\end{array}$ \\
\hline 1986 & ADEA amendments & $\begin{array}{l}\text { Eliminated upper age limit, thus banning mandatory } \\
\text { retirement, with very limited exemptions. }\end{array}$ \\
\hline 1990 & $\begin{array}{l}\text { Older Workers Benefit } \\
\text { Protection Act }\end{array}$ & \begin{tabular}{l} 
Regulated financial inducements to retire. \\
\hline
\end{tabular} \\
\hline
\end{tabular}


Table 2: Receipt of Discrimination Charges by EEOC, by Issue (2000 Fiscal Year, Preliminary)

\begin{tabular}{|c|c|c|c|c|c|c|}
\hline \multirow[t]{2}{*}{ Statute: } & \multicolumn{2}{|c|}{ ADEA } & \multicolumn{2}{|c|}{ Title VII } & \multicolumn{2}{|c|}{ All statutes } \\
\hline & Total & Column \% & Total & Column \% & Total & Column \% \\
\hline Selected issues: & & & & & & \\
\hline Benefits & 468 & 1.9 & 1033 & 1.0 & 1986 & 0.9 \\
\hline Benefits, retirement/pension & 1620 & 6.6 & 283 & 0.3 & 2042 & 0.9 \\
\hline Discharge & 6763 & 27.5 & 26346 & 24.9 & 41902 & 19.3 \\
\hline Hiring & 1973 & 8.0 & 3320 & 3.1 & 6548 & 3.1 \\
\hline Layoff & 1137 & 4.6 & 1793 & 1.7 & 3465 & 1.6 \\
\hline Promotion & 1645 & 6.7 & 7415 & 7.0 & 10047 & 4.6 \\
\hline Retired, unvoluntary & 217 & 0.9 & 83 & 0.1 & 372 & 0.2 \\
\hline Sexual harassment & 266 & 1.0 & 9328 & 8.8 & 10064 & 4.6 \\
\hline Terms of employment & 2578 & 10.5 & 13806 & 13.0 & 19178 & 8.8 \\
\hline Wages & 1099 & 4.5 & 6188 & 5.8 & 9013 & 4.2 \\
\hline Total issues & 24586 & & 105854 & & 216839 & \\
\hline Total charges & 15926 & & 59215 & & 79325 & \\
\hline
\end{tabular}

Note: The number of issues exceeds the number of charges because individuals may file charges claiming multiple types of discrimination. 
Table 3: EEOC Administrative and Legal Activity, 1999 Fiscal Year

\begin{tabular}{|c|c|c|c|c|c|c|}
\hline \multirow[t]{2}{*}{ Statute: } & \multicolumn{2}{|c|}{ ADEA } & \multicolumn{2}{|c|}{ Title VII } & \multicolumn{2}{|c|}{ All statutes } \\
\hline & Total & Column \% & Total & Column \% & Total & Column \% \\
\hline \multicolumn{7}{|c|}{ A. Resolutions by Type } \\
\hline Settlements & 816 & 5.3 & 3748 & 6.3 & 6094 & 6.2 \\
\hline Withdrawals with benefits & 578 & 3.7 & 2084 & 3.5 & 3593 & 3.7 \\
\hline Administrative closures & 3601 & 23.3 & 14265 & 24.1 & 23570 & 24.1 \\
\hline No reasonable cause & 9172 & 59.4 & 35614 & 60.3 & 58174 & 59.5 \\
\hline Reasonable cause & 1281 & 8.3 & 3374 & 5.7 & 6415 & 6.6 \\
\hline Total resolutions & 15448 & & 59085 & & 97846 & \\
\hline \multicolumn{7}{|c|}{ B. Breakdown of Reasonable Cause Determinations } \\
\hline Successful conciliations & 184 & 14.4 & 859 & 25.5 & 1578 & 24.6 \\
\hline Unsuccessful conciliations & 1097 & 85.6 & 2515 & 74.5 & 4837 & 75.4 \\
\hline \multicolumn{7}{|c|}{ C. Litigation and Monetary Benefits } \\
\hline $\begin{array}{l}\text { Lawsuits filed by EEOC or } \\
\text { joined by EEOC }\end{array}$ & 40 & & 324 & & 439 & \\
\hline $\begin{array}{l}\text { Monetary benefits from } \\
\text { litigation (millions) }\end{array}$ & $\$ 43.3$ & & $\$ 46.9$ & & $\$ 96.9$ & \\
\hline $\begin{array}{l}\text { Monetary benefits excluding } \\
\text { litigation (millions) }\end{array}$ & $\$ 38.6$ & & $\$ 119.1$ & & $\$ 210.5$ & \\
\hline
\end{tabular}

Note: In the litigation figures (Panel C), the total column includes cases filed under more than one statute, sometimes including the ADEA or Title VII. 
Table 4: Key Court Decisions Regarding Age Discrimination

\begin{tabular}{|l|l|l|}
\hline \multicolumn{1}{|c|}{ Year } & \multicolumn{1}{|c|}{ Decision } & \multicolumn{1}{c|}{ Content } \\
\hline 1971 & Griggs vs. Duke Power Co. & Established disparate impact cases. \\
\hline 1973 & McDonnell Douglas v. Green & $\begin{array}{l}\text { Established evidence and burden of proof for } \\
\text { intentional discrimination. }\end{array}$ \\
\hline 1976 & $\begin{array}{l}\text { Mastie v. Great Lakes Steel } \\
\text { Corp. }\end{array}$ & $\begin{array}{l}\text { Allowed employer to look at salary and fringe benefit } \\
\text { costs in reduction in force cases, as long as decision is } \\
\text { based on individual assessment. }\end{array}$ \\
\hline 1977 & $\begin{array}{l}\text { International Board of } \\
\text { Teamsters v. United States }\end{array}$ & $\begin{array}{l}\text { Established disparate treatment cases. } \\
\text { Comas Department of }\end{array}$ \\
\hline 1987 & $\begin{array}{l}\text { Metz v. Transit Mix, Inc. } \\
\text { Established evidence and burden of proof for } \\
\text { intentional discrimination. }\end{array}$ \\
\hline 1993 & $\begin{array}{l}\text { Ruled that allowing a company to replace an employee } \\
\text { based on the higher cost of employing him could } \\
\text { violate the intent of the ADEA. }\end{array}$ \\
\hline
\end{tabular}


Table 5: Evidence on the Effectiveness of Age Discrimination Legislation

\begin{tabular}{|c|c|c|}
\hline Study & Period covered & Findings \\
\hline \multicolumn{3}{|r|}{ A. Direct Evidence } \\
\hline $\begin{array}{l}\text { Neumark and } \\
\text { Stock (1999) }\end{array}$ & $1940-1980$ & $\begin{array}{l}\text { State and federal anti-age discrimination statutes boost } \\
\text { employment of workers aged } 60 \text { and over by about six } \\
\text { percentage points. No discernible effect of elimination of } \\
\text { mandatory retirement, but test is weak. }\end{array}$ \\
\hline Adams (2000) & $1964-1967$ & $\begin{array}{l}\text { State anti-discrimination statutes boost employment of } \\
\text { workers aged } 60 \text { and over by about } 5.5 \text { percentage points. } \\
\text { State anti-discrimination statutes have little effect on the } \\
\text { relative probability that an older worker is a new hire, } \\
\text { although there is some evidence of negative effects for } \\
\text { workers aged } 65-70 \text {. State anti-discrimination statutes also } \\
\text { reduce retention of older workers. But retirements fall } \\
\text { substantially, overwhelming these effects and leading to the } \\
\text { increase in employment. }\end{array}$ \\
\hline $\begin{array}{l}\text { Ashenfelter and } \\
\text { Card (2000) }\end{array}$ & $1986-1996$ & $\begin{array}{l}\text { Elimination of mandatory retirement for professors resulted in } \\
\text { large reductions in retirements at or just beyond the previous } \\
\text { retirement age. }\end{array}$ \\
\hline \multicolumn{3}{|c|}{ B. Continuing Evidence of Age Discrimination } \\
\hline Hutchens (1988) & 1983 & $\begin{array}{l}\text { Older new hires are clustered in a narrower set of industries } \\
\text { and occupations than younger new hires or all older workers. }\end{array}$ \\
\hline $\begin{array}{l}\text { Hirsch, et al. } \\
(2000)\end{array}$ & 1983-1998 & $\begin{array}{l}\text { Occupations that are less open to older new hires have steeper } \\
\text { experience profiles and higher prevalence of pensions. } \\
\text { Exclusion of older new hires has fallen only slightly if at all. }\end{array}$ \\
\hline Adams (2000) & $1992-1994$ & $\begin{array}{l}\text { Self-reported age discrimination with respect to promotions is } \\
\text { associated with lower subsequent wage growth, and higher } \\
\text { self-assessed probability of retirement at age } 62 \text { or } 65 \text {. }\end{array}$ \\
\hline \multicolumn{3}{|r|}{ C. Critiques of the ADEA } \\
\hline $\begin{array}{l}\text { Neumark and } \\
\text { Stock (1999) }\end{array}$ & $1940-1980$ & $\begin{array}{l}\text { Age discrimination legislation resulted in steepening of age- } \\
\text { earnings profiles for new labor market entrants. }\end{array}$ \\
\hline
\end{tabular}

